\title{
Cyclic activity of the pituitary prolactin cells and plasma prolactin levels in the oestrous cycle of the ewe
}

\author{
Jolanta Polkowska, Ewa Wolińska and E. Domanski \\ Institute of Animal Physiology and Nutrition, 05-110 Jablonna near Warsaw, Poland
}

\begin{abstract}
Summary. The relative proportions of prolactin cells, somatotrophs and gonadotrophs were determined in the adenohypophyses of 28 Merino ewes on selected days during the oestrous cycle. Plasma prolactin levels were measured in 16 of the animals at 3-hr intervals during the $24 \mathrm{hr}$ before autopsy. From Days 1 to 5 of the cycle (Day 0=day of ovulation), plasma prolactin levels were $20-40 \mathrm{ng} / \mathrm{ml}$ and the prolactin cells were filled with granules. Plasma levels increased to $168 \mathrm{ng} / \mathrm{ml}$ between Days 6 and 9, and marked degranulation of the prolactin cells occurred. The greatest degranulation was found on Days 16 and 0 , and was associated with a prolactin surge to a concentration of $610 \mathrm{ng} / \mathrm{ml}$. The rise in plasma prolactin and intensive degranulation of prolactin cells at the time of ovulation and formation of the CL suggest that prolactin is important at this stage of the oestrous cycle.
\end{abstract}

\section{Introduction}

Although numerous papers on the secretion and function of prolactin (lactotrophic hormone, LTH) during the oestrous cycle have been published, the physiological role of this hormone in the oestrous cycle of the ewe remains to be clarified. Most authors are of the opinion that prolactin is not involved in the reproductive processes in sheep and cattle (Santolucito, Clegg \& Cole, 1960; Kaltenbach, Graber, Niswender \& Nalbandov, 1968; Louw, Lishman, Botha \& Baumgartner, 1974; Hoffman et al., 1974) and argue that luteotrophic activity is adequately provided by LH. Some recent studies, however, present a different view. For instance, experiments in hypophysectomized or stalksectioned sheep show that only prolactin can maintain the secretory activity of the CL (Denamur, Martinet \& Short, 1970, 1973; Bryant, Greenwood, Kann, Martinet \& Denamur, 1971; Kann \& Denamur, 1974) and are in accord with the findings of Domański, Skrzeczkowski, Stupnicka, Fitko \& Dobrowolski (1967) that LTH in sheep stimulates the secretion of progesterone by the perfused ovary on the 7 th and 8 th days of the oestrous cycle. Measurements of serum prolactin levels by radioimmunoassay throughout the oestrous cycle in sheep have indicated marked changes with release at a very high rate just before ovulation, and with the peak preceding that of LH (Reeves, Arimura \& Schally, 1970; Bryant et al., 1971; Davis, Reichert \& Niswender, 1971; Cumming, Brown, Goding, Bryant \& Greenwood, 1972). Distinct changes in the amount of degranulation in prolactin cells have been found to be associated with the various physiological stages of pregnancy and lactation in sheep (Domański \& Polkowska, 1973), suggesting that the changes in the prolactin cells throughout the oestrous cycle would also reflect release of the hormone. The present study, therefore, examined the histology of the pituitary prolactin cells and the corresponding plasma prolactin levels at various stages of the oestrous cycle in sheep.

\section{Materials and Methods}

The experiments were carried out on 28 Merino ewes. The pituitaries of all the ewes were studied histologically, while prolactin concentration in the plasma was determined only in 16 of the animals. The oestrous cycle was checked by running the ewes with a vasectomized ram and by 
inspection of the ovaries at laparotomy, and 1,2 or 3 animals were killed on each day of the oestrous cycle. Pituitary glands were removed immediately after sl:ughter and fixed in Bouin's solution with trichloroacetic acid (Halmi, 1952) and formol sublimate for $72 \mathrm{hr}$. After fixation and embedding in paraplast they were cut into $2 \cdot 5-3.0 \mu \mathrm{m}$ serial frontal sections and stained by the following methods: (1) Herlant's tetrachrome technique (Herlant, 1960); (2) periodic acid-Schifforange G (Wilson \& Ezrin, 1954); (3) aldehyde fuchsin-Schiff-orange G (Elftman, 1959); (4) Brookes technique (Brookes, 1968). All the staining procedures were adapted for the pituitaries of sheep in that the time of staining and differentiation of the cells was modified, the procedures of preparing solution of dyes were changed in the methods (1) and (2), and in method (4) azo fuchsin G was used instead of carmoisine L and fast green FCF instead of wool green. In the sections, prolactin cells, somatotrophs, gonadotrophs and chromophobes were differentiated (Van Oordt, 1965), counted in a total of about 3000 cells and expressed as a percentage of the cell population in each pituitary. The results were evaluated statistically by analysis of variance. Blood samples were collected from the jugular vein at $3-\mathrm{hr}$ intervals during the $24 \mathrm{hr}$ before slaughter. Prolactin concentration was estimated by a radioimmunoassay-double-antibody method described for bovine prolactin by Schams \& Karg (1969) modified by R. Stupnicki \& A. Madej (unpub.). Ovine prolactin (2.5 $\mu \mathrm{g}$ ) was iodinated by a modification of the method of Bryant \& Greenwood (1968), using $1 \mathrm{mCi}{ }^{125} \mathrm{I}$ and $20 \mu \mathrm{g}$ chloramine $\mathrm{T}$. Unreacted iodine-125 was removed by gel filtration on a column of Sephadex G-50. The labelled ovine prolactin was further purified through a column of Sephadex G-100 equilibrated with $0 \cdot 1 \mathrm{M}$-veronal buffer, $\mathrm{pH} 8.6$. Purified ovine prolactin, produced in our Institute, was used as the antigen for radioimmunoassay. The standard curves of the prolactin preparation (ovine and bovine) were compared with the curve of bovine prolactin (NIH-B-3) and found to be identical. The blood plasma samples were stored at $-20^{\circ} \mathrm{C}$ until assayed. The results were evaluated statistically by analysis of variance.

\section{Results}

The prolactin cells formed the major category of cells in the adenohypophysis of the sheep. They amounted to about $50 \%$ of the total cell population in met- and dioestrus compared to $17 \%$ somatotrophs and $13 \%$ gonadotrophs (Text-fig. 1). Throughout the oestrous cycle the prolactin cells showed striking changes in structure and number. The amount of degranulation varied with the stage of the cycle. Most intensive degranulation was observed on Day 16 and Day 0 (Day $0=$ day of ovulation; PI. 1, Figs 2 and 3), and occurred in large areas of the gland. Degranulated prolactin cells (counted as chromophobes) were the predominant cell group, while the number of granulated lactotrophs decreased abruptly from 50 to $26 \%$ at this time (Text-fig. 1). The histological picture was very similar to that of the pituitary of a lactating ewe and showed increase of cell size and enlarged and irregularly shaped nuclei. The granules were observed in prolactin cells as early as $10 \mathrm{hr}$ after ovulation (Pl. 1, Fig. 4). The cells became progressively filled with granules whose affinity for acidophilic dyes was increasing. During Days 1 and 2, the characteristic picture of strongly stained prolactin cells situated around the blood vessels was observed (Pl. 1, Fig. 5) and the proportion increased to $50 \%$ (Text-fig. 1). A second degranulation of prolactin cells was observed between Days 7 and 9 (Pl. 1, Fig. 6) but it was less severe than that on Day 16. During Days 10-15 no signs of degranulation of the prolactin cells were found; they were filled with hormonal granules and closely packed in clusters (PI. 1, Fig. 1). At this time an increase in the number of gonadotrophs was noticed (Text-fig. 1). These cells, especially during the 3 days before ovulation, were hypertrophied and abundantly filled with hormone granules; intensive degranulation of these cells occurred on Day 0. No morphological changes were seen in the somatotrophs and their number was nearly constant on all the days of the oestrous cycle (Text-fig. 1).

The plasma prolactin concentrations were variable. The basal level oscillated from 5 to $40 \mathrm{ng} / \mathrm{ml}$ (Text-fig. 1). At the beginning of the cycle concentrations were at basal levels but increased signifcantly to $168 \mathrm{ng} / \mathrm{ml}$ on Day $6(P<0.01)$. Another rise occurred on Day 9 but levels were low on Days 10-12, becoming elevated again on Day 14 and reaching maximal values $(610 \mathrm{ng} / \mathrm{ml})$ on Day 16 . 
PLATI: 1
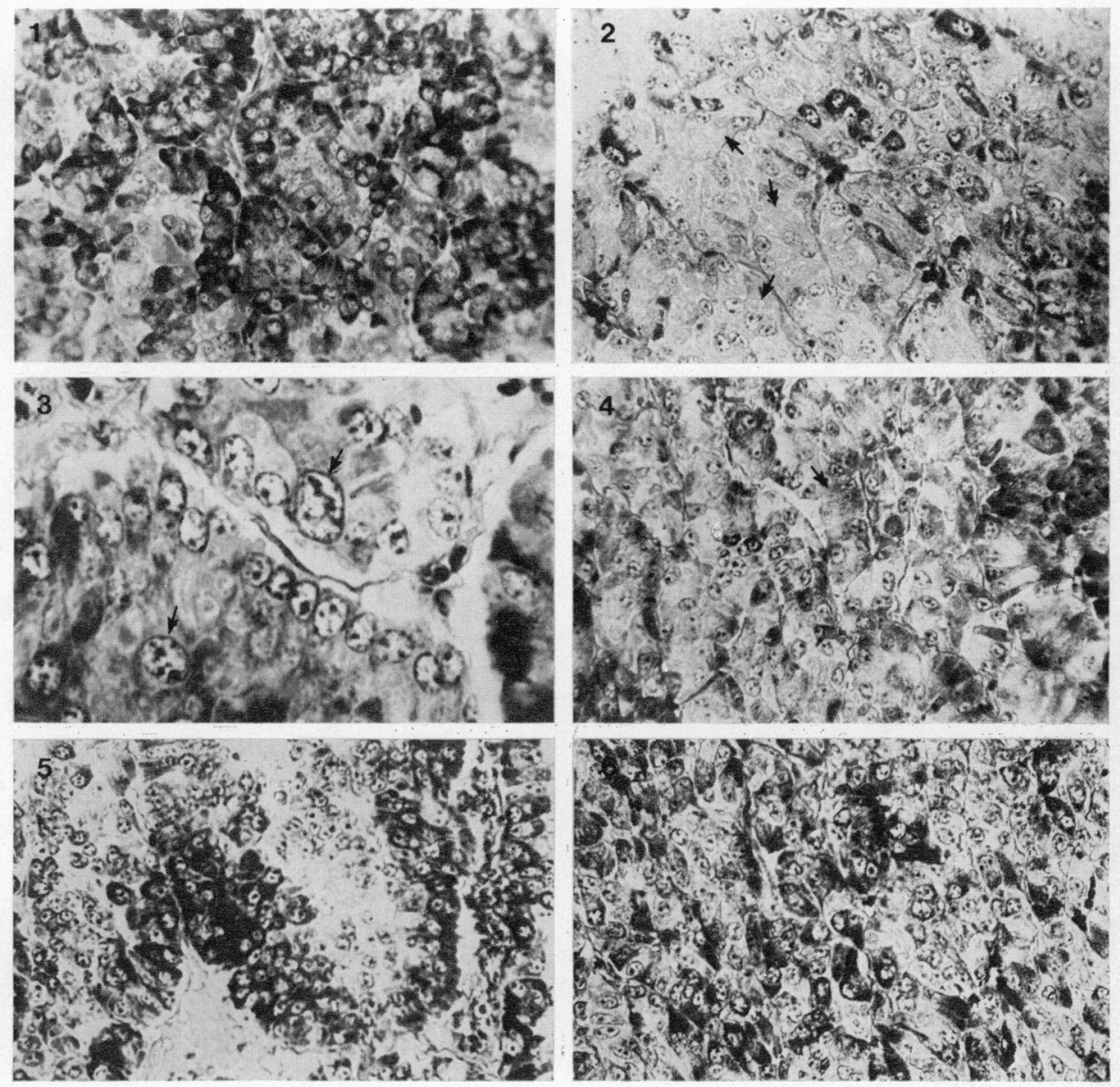

Fig. 1. The adenohypophysis of a cwe on Day 15 of the oestrous cycle. Prolactin cells (black) are filled with granules and arranged in clusters. Brooke's stain, $\times 267$.

Fig. 2. Day 16 of the cycle, showing the advanced degranulation of prolactin cells (pale cells, arrowed). At lower right there is a group of non-degranulated prolactin cells (black). Herlant's tetrachrome, $\times 267$.

Fig. 3. Adenohypophysis on the day of ovulation (Day 0), showing degranulated prolactin cells with enlarged irregular nuclei (arrowed). PAS orange $G, \times 408$.

Fig. 4. The pituitary $10 \mathrm{hr}$ after ovulation. The prolactin cells (grey, arrowed) are becoming filled with hormone granules again. Aldehyde fuchsin-PAS-orange G, $\times 267$.

Fig. 5. On Day 1 of the cycle, the prolactin cells are strongly stained and situated just around the blood vessels. More remote cells are still degranulated. Herlant's tetrachrome, $\times 267$.

Fig. 6. On Day 9 of the cycle, the prolactin cells (pale) are degramulated again, although some are filled with granules (grey and black). Herlant's tetrachrome, $\times 267$. 


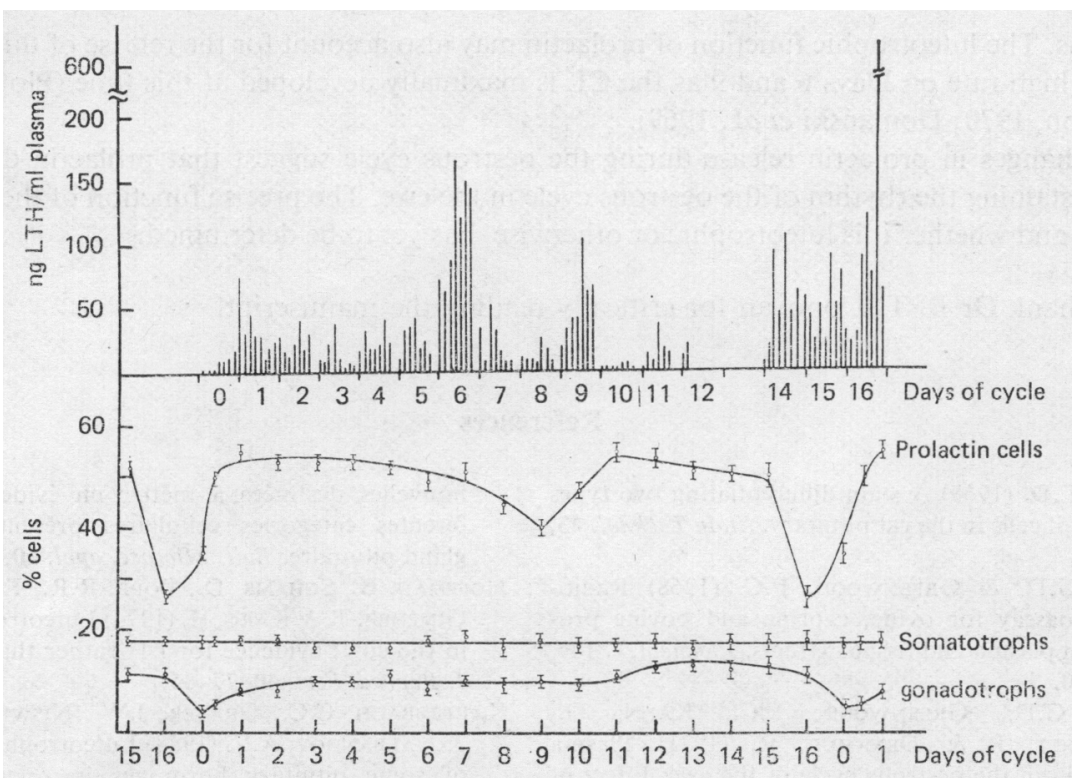

Text-fig. 1. Graph showing the various amounts of the three cell types in the adenohypophysis (mean+S.E.M.) and prolactin concentration in blood plasma during particular days of the oestrous cycle in sheep.

\section{Discussion}

The degranulation of prolactin cells throughout the oestrous cycle shows a great resemblance in feature and prominence to that seen during lactation (Domański \& Polkowska, 1973), and suggests the release of prolactin. This suggestion is strongly supported by the measurements of plasma prolactin. Degranulation of the prolactin cells was generally associated with a rise in concentration of prolactin in peripheral blood, e.g. the increasing degranulation between Days 7 and 9 of the oestrous cycle was associated with the high levels of prolactin determined on Days 6 and 9 . Furthermore, the surge of the hormone on Day 16 was followed by an intensive degranulation of the prolactin cells on Days 16 and 0 . The high levels of plasma prolactin on Days 14 and 15 of the cycle were not, however, reflected by the degranulation of the cells. This discordance may have arisen from the small number of animals used but the histological results accord with the low serum prolactin concentrations for this stage of the cycle reported by others (Reeves et al., 1970; Bryant et al., 1971; Davis et al., 1971).

The progesssive degranulation of prolactin cells throughout the oestrous cycle seems to be a characteristic histological feature of the sheep adenohypophysis. The changes were much more marked than those in gonadotrophs, although this group of pituitary cells is claimed to play the main role in the control of the oestrous cycle. Prolactin cells are also more numerous than the gonadotrophs, e.g. $55.5 \%$ prolactin cells and $11.6 \%$ gonadotrophs on Day 11 . The rapid decrease in the number of granulated prolactin cells (from 50 to $26 \%$ ) implies the liberation of large amounts of the hormone. This supposition is supported by the results of radioimmunoassays. The high concentration of prolactin on Day 16 of the cycle was about three to four times higher than the plasma concentration of LH at the same time (Kann, 1971; E. Wolińska, unpublished). Kann \& Denamur (1974) believe that prolactin plays a luteotrophic role in the oestrous cycle of the ewe, but that more prolactin is secreted than is needed for this purpose. They interpret preovulatory surges of prolactin and $\mathrm{LH}$ as the signal for the start of the development of the CL. Different interpretation of the preovulatory peak of prolactin are possible; Reeves et al. (1970) and Davis et al. (1971) suggested that high levels of prolactin correspond only to a simultaneous increase of blood 
oestrogens. The luteotrophic function of prolactin may also account for the release of this hormone at a very high rate on Days 6 and 9 as the $C L$ is maximally developed at this time (Plotka, Erb \& Harrington, 1970; Domański et al., 1969).

The changes in prolactin release during the oestrous cycle suggest that prolactin does play a role in sustaining the rhythm of the oestrous cycle in the ewe. The precise function of the hormone, however, and whether it is luteotrophic or otherwise, has yet to be determined.

We thank Dr B. T. Donovan for critically reading the manuscript.

\section{References}

Brookes, L.D. (1968) A stain differentiating two types acidophil cells in the rat pituitary. Stain Technol. 43, $41-42$.

Bryant, G.D. \& Greenwood, F.C. (1968) Radioimmunoassay for ovine, caprine and bovine proIactin in plasma and tissue extracts. Biochem. J.109, 831-840.

Bryant, G.D., Greenwood, F.C., KanN, G., Martinet, J. \& Denamur, R. (1971) Plasma prolactin in the oestrous cycle of the ewe. Effect of pituitary stalk section. J. Endocr. 51, 405-406.

Cumming, I.A., Brown, J.M., Goding, J.R., BRYant, G.D. \& GReENwood, F.S. (1972) Secretion of prolactin and luteinizing hormone at oestrus in the ewe. J. Endocr. 54, 207-213.

Davis, S.L., Reichert, L.E., JR \& Niswender, G.D. (1971) Serum levels of prolactin in sheep as measured by radioimmunoassay. Biol. Reprod. 4, 145-153.

Denamur, R., Martinet, J. \& Short, R.V. (1970) Mode of action of oestrogen in maintaining the functional life of corpora lutea in sheep. J. Reprod. Fert. 23, 109-116.

Denamur, R., Martinet, J. \& ShorT, R.V. (1973) Pituitary control of the ovine corpus luteum. $J$. Reprod. Fert. 32, 207-220.

Domański, E. \& Polkowska, J. (1973) The hypothalamic areas involved in the control of mammotrophic and lactotrophic processes in sheep. Endocr. exp. 7, 229-246.

Domański, E., Skrzeczkowski, L., Stupnicka, E., Fitko, F. \& Dobrowolski, W. (1967) Effect of gonadotrophins on the secretion of progesterone and oestrogens by the sheep ovary perfused in situ. J. Reprod. Fert. 14, 365-372.

Elftman, M. (1959) Combined aldehyde fuchsin and periodic acid staining of the pituitary. Stain Technol. 34, 77-84.

Halmi, N.S. (1952) Differentiation of two types of basophils in the adenohypophysis of the rat and mouse. Stain Technol. 27, 61-64.

Herlant, M. (1960) Étude critique de deux techniques nouvelles destinées a mettre en évidence les différentes catégories cellulaires présentes dans la gland pituitaire. Bull. Microsc. appl. 10, 37-44.

Hoffman, B., Schams, D., Bopp, R R., Ender, M.L., GimÉNEZ, T. \& KARG, H. (1974) Luteotrophic factors in the cow: evidence for LH rather than prolactin. J. Reprod. Fert. 40, 77-85.

Kaltenbach, C.C., Graber, J.W., Niswender, G.D. \& NaLbandov, A.V. (1968) Luteotrophic properties of some pituitary hormones in nonpregnant or pregnant hypophysectomized ewes. Endocrinology 82, 818-824.

KANN, G. (1971) Variations des concentrations plasmatiques de l'hormone lutéinisante et la prolactine au cours du cycle oestrum de la Brebis. C. r. hebd. Séanc. Acad. Sci., Paris 272, 2934-2937.

Kann, G. \& Denamur, R. (1974) Possible role of prolactin during the oestrous cycle and gestation in the ewe. J. Reprod. Fert. 39, 473-483.

Louw, B.P., Lishman, A.W., Botha, W.A. \& BAUmgartner, J.P. (1974) Failure to demonstrate a role for the acute release of prolactin at oestrus in the ewe. J. Reprod. Fert. 40, 455-457.

Plotka, E.D., Erb, R.E. \& Harkington, R.B. (1970) Female sex steroid relationship during the estrous cycle of the ewe. J. Anim. Sci. 30, 412-419.

Reeves, J.J., Arimura, A. \& Schally, A.V. (1970) Serum levels of prolactin and luteinizing hormone (LH) in the ewe at various stages of the estrous cycle. Proc. Soc. exp. Biol. Med. 134, 938-942.

Santolucito, J.A., ClegG, M.T. \& Cole, H.H. (1960) Pituitary gonadotrophins in the ewe at different stages of the estrous cycle. Endocrinology 66, 273-279.

Schams, D. \& KarG, H. (1969) Radioimmunologische Bestimmung von Prolaktin in Blutserum vom Rind. Milchwissenschaft 24, 263-265.

VAN OORDT, P.G.W.J. (1965) Nomenclature of the hormone-producing cells in the adenohypophysis. Gen. comp. Endocr. 5, 131-134.

Wilson, W.D. \& Ezrin, C. (1954) Three types of the adenohypophysis. Am. J. Path. 30, 891-899.

Received 7 May 1975 